\title{
住環境保全を目的とした自主ルールの実効性を高める住民組織の取り組み 一行政指導を変化させた町田市に抢ける建築協約を事例としてー \\ ACTIVITIES BY RESIDENTIAL ASSOCIATIONS IN ORDER TO ENHANCE EFFECTIVENESS OF COMMUNITY RULES FOR RESIDENTIAL ENVIRONMENT PROTECTION \\ - Cases of Kenchiku-Kyoyaku in Machida city through transfer of administrative supports -
}

\author{
堂免隆浩* \\ Takahiro DOMEN
}

\begin{abstract}
In order to enhance effectiveness on Kenchiku-Kyoyaku, its enforcement was supported by the administrative guidance. However, the amount of administrative supports has decreased Therefore residential associations must maintain its enforcement themselves. Its activities are 1)the persuasion to constructors into changing constructors' mismatched plan, 2)the monitoring of constructors before their construction and building confirmation, and 3)the enforcement of Kenchiku-Kyoyaku by administration. And the conditions of effective activities are following: 1)the awareness of destruction of residential environment among residents, 2)the information about private building inspection agencies frequently used by constructors, and 3) the estimation of lower cost to reach consensus among residents.
\end{abstract}

Keywords : Residential environment protection, Administrative guidance, Community association, Kenchiku-Kyoyaku 住環境保全，行政指導，住民組織，建築協約

\section{1. 研究の背景と目的}

自主ルールの実効性は、法的な裏付けがない代わりに、行政指導 により維持されてきた。住環境の保全を目的として、必ずしも法律 の裏付けをもたないものの、住民により制定された自主ルールが多 〈存在している 1）2）。一見、自主ルールは、法律の裏付がないため 実効性に欠けると考えられる。そのため、法的な担保が必要である という考え方に基づき、条例の制定が行われ、条例の裏付けをもつ ルールに関寸る研究が進んでいる ${ }^{3)}$ 。一方で、法律あるいは条例の 裏付けのないルールであるにもかかわらず、違反計画の約 8 割を変 更や中止、撤回させ、住環境管理の効果が全体的に高いことが示さ れている 2) 4)。そして、この効果の高さは、事前協議の指導および 計画の事前通知という行政指導に支えられているとされている。

1993 年の行政手続法の制定および 1998 年の建築基準法改正に伴 う建築確認業務の民間開放は、行政指導の効力を減少させると考え られる。行政手続法では、建築確認等において行政指導により申請 者の権利の行使を妨げてはならないことが明記された注1。そのため、 行政による事前協議の指導の実効性は弱まると考えられる。また、 建築確認による審查業務および検査業務が指定確認検查機関に開放 されたことで、建築確認申請前における行政による計画の事前通知 を漏れなく実施することが困難になると考えられる。

既存研究では、行政手続法あるいは建築確認業務の民間開放が自 主ルールの実効性へ及ぼす影響について明らかにしたものは少ない。 行政手続法が住環境保全へ及ぼす影響に注目した既存研究では 5)、
住環境等が地域的共通利益であると法的に認定できるとし、利害調 整手続きおよび合意形成手続きに反映させることが提案されている。 また、建築確認業務の民間開放が住環境保全へ及ぼす影響に注目し た既存研究では ${ }^{6}$ 7)、条例の裏付けを持つ事前協議が提案されてい る。ただし、これらの既存研究は、自主ルールに及ぶ影響までは扱 っていない。さらに、解決を法に求めるのみであり、必ずしも住民 自らによる解決は考察されていない。また、自主ルールを対象にし た既存研究では、自主ルールそのものの効果 ${ }^{2}$ 、もしくは、地区計 画との併用による効果 $\left.{ }^{8}\right)$ を考察したものがある。ただし、これらは 一時点の効果に着目寸るのみであり、行政指導の変化の影響まで考 察されていない。さらに、住民組織における活動の拡大を扱った既 存研究では ${ }^{9)}$ 、地縁組織との連携があることで建築協定運営委員会 の活動の幅が拡大寸ることが示されている。ただし、必ずしも行政 指導の減少を補う活動に焦点が当てられていない。

本研究の大きな問題意識は、必ずしも法の裏付けを持たない、住 民主体による住環境保全が実現可能か、にある。この問題意識に基 づき本研究では、行政手続法の制定あるいは建築確認業務の民間開 放が自主ルールの実効性に及ぼす影響を確認し、自主ルールの実効 性を高めるための住民組織による取り組み、および、それらの取り 組みを実施できる条件を明らかにすることを目的とする。

\section{2. 研究の方法}

町田市における「建築協約」は、行政指導による支援を受けてい

\footnotetext{
* 一橋大学大学院社会学研究科 専任講師 ·博士(工学) Lecturer, Graduate School of Social Sciences, Hitotsubashi University, Dr. Eng.
} 
た自主ルールである。建築協約は、町田市 T 地域において初めて利 用された名称である。当初、住民の一部が建築協定の締結を目指し ていた。しかし、全員の合意が得られず頓挫してしまった。そこで、 住民、市長、および、建築指導課と協議し、土地の所有者等の $80 \%$ の合意を得ることで「建築協約」を制定できることとした。「建築協 約」は法律の裏付けを持たないことから、行政指導により建築主な らびに建築業者の理解を得ることとした注2)。2010 年 4 月時点で、 町田市内における建築協約は 25 存在する。ただし、本研究では、行 政指導による支援を前提とした自主ルールの傾向が強いと考えられ る $\mathrm{T}$ 地域を対象と寸る注3)。T 地域には 5 つの建築協約が制定され、 それぞれ異なる団体が運用している。

本研究では、まず 2010 年 4 月に町田市建築指導課より $\mathrm{T}$ 地域の建 築協約書、および、連絡空口である建築協約委員会注 4) の連絡先を 入手した。そして、建築協約の運用実態を確認するため、各建築協 約の代表者に対しインタビュー調査を行った (表 1 参照)。次に、行 政および指定確認検查機関における建築協約の現在の取り扱いを確 認するため、町田市建築指導課および指定確認検查機関 2 社注 ${ }^{5)}$ に 対しインタビュー調査を行った (表 2 参照)。

表 1 建築協約の運用に関する調查概要

\begin{tabular}{|c|c|c|c|c|}
\hline 調査日 & \multicolumn{4}{|c|}{ 2010年6月 } \\
\hline 調査方法 & \multicolumn{4}{|c|}{ 対面によるインタビュー調査 } \\
\hline \multirow{11}{*}{ 調査対象 } & 協約名 & 対象者 & （役職名 & :従事年数) \\
\hline & A協約 & a1 & （建築協約対策委員 & 8年） \\
\hline & \multirow{4}{*}{ B協約 } & b1 & （建築協約特別委員 & 6年） \\
\hline & & b2 & （建築協約特別委員 & 4年） \\
\hline & & b3 & （建築協約特別委員 & 3 年) \\
\hline & & b4 & （建築協約特別委員 & 2年) \\
\hline & C協約 & $\mathrm{c} 1$ & （建築協約審議委員 & $: 11$ 年） \\
\hline & \multirow{3}{*}{ D協約 } & d1 & （建築協約対策委員 & :22年） \\
\hline & & & （建築協約対策委員 & :20年） \\
\hline & & d3 & （建築協約対策委員 & :17年) \\
\hline & E協約 & $\mathrm{e} 1$ & (会長 & :10年) \\
\hline
\end{tabular}

表 2 行政および指定確認検査機関における建築協約の対応に 関する調查概要

\begin{tabular}{|l|l|}
\hline 調査日 & 2010年7月 \\
\hline 調査方法 & 電話によるインタビュー調查 \\
\hline 調査対象 & $\begin{array}{l}\text { 町田市建築指導課 } \\
\text { 指定確認検查機関 }(2 \text { 社 })\end{array}$ \\
\hline
\end{tabular}

\section{T地域の成り立ちと建築協約の制定}

\section{3-1. T地域の開発}

$\mathrm{T}$ 地域は、1953 年に発表された「城西南地区開発趣意書」(多摩 田園都市構想）に基づく開発地域の一つである注 6)。位置は、町田市 の中心部から東南約 $5 \mathrm{~km}$ である。 $\mathrm{T}$ 地域では、1965 年より組合施 工による第一期土地区画整理事業が行われた。東急不動産が事業受 託し、約 95ha の区域が開発された。東急不動産が地主より買い上 げた土地は全体の約 7 割を占める。そして、分譲された住宅地は一 区画当たり $70 \sim 80$ 坪である。なお、第一期開発区域は、建築協約 における $\mathrm{A} \sim \mathrm{C}$ 協約区域に含まれる。つづいて、1968 年より、組合 施工による第二期土地区画整理事業が行われた。東急不動産が事業 受託し、約 70ha の区域が開発された。東急不動産が地主より買い 上げた土地は全体の約 3 割を占める。そして、分譲された住宅地は 一区画当たり 50 ～60 坪である。なお、第二期開発区域は、建築協 約における D 協約区域に含まれる。

\section{3-2. T地域における建築協約の締結}

$\mathrm{T}$ 地域における建築協約数は 5 であり、自治会による運用が 4 、 任意団体による運用が 1 である。表 3 は、各自治会における建築協 約名、効力発効日、および、効力が及ぶ範囲を示している。また、 図 1 は、効力が及ぶ範囲を図示している。

T 地域における建築協約のきっかけには、建築上のトラブルへの 対応、および、既存の建築協約への反対の側面が存在する。1975 1977 年にかけて、建築上のトラブルが頻発した。これに対し、A 自 治会は、当時の市長および建築指導課と話し合いを重ね、建築協約 を発案した。そして、各家庭に「賛否のアンケート」を配布し、多 数の賛同を得て $\mathrm{A}$ 協約が制定された。 A 協約の効力が及ぶ範囲は、 A 自治会区域であり区域(1)と区域(2)に分割されている。区域(1)は、 A 協約が試験導入された区域である。区域(2)、、域(1)の試験導入 が成功後、追加指定されている。効力発効日は、区域(1) 1976 年 2 月 1 日、区域(2)が 1976 年 11 月 1 日である。つづいて、B〜D 自治 会においても、A 協約を参考にして建築協約の制定が進められた。 各家庭に「賛否のアンケート」を配布し、多数の賛同を得て $\mathrm{B} \sim \mathrm{D}$

表 3 各自治会における建築協約の効力

\begin{tabular}{|c|c|c|c|c|c|}
\hline & A自治会 & B自治会 & C自治会 & D自治会 & E会 \\
\hline 建築協約名 & A協約 & B協約 & C協約 & D協約 & E協約 \\
\hline $\begin{array}{c}\text { 効カが及ぶ } \\
\text { 範囲 }\end{array}$ & $\begin{array}{c}\text { 運営団体で } \\
\text { あるA自治 } \\
\text { 会区域 }\end{array}$ & $\begin{array}{c}\text { 運営団体で } \\
\text { あるB自治 } \\
\text { 会区域 }\end{array}$ & $\begin{array}{c}\text { 運営団体で } \\
\text { あるC自治 } \\
\text { 会区域 }\end{array}$ & $\begin{array}{c}\text { 運営団体で } \\
\text { あるD自治 } \\
\text { 会区域 }\end{array}$ & $\begin{array}{c}A \sim C \text { 協約区 } \\
\text { 域に土地を } \\
\text { 所有してい } \\
\text { る会員 }\end{array}$ \\
\hline $\begin{array}{l}\text { 効力 } \\
\text { 発効日 }\end{array}$ & \begin{tabular}{|} 
区域(1): \\
1976.2 .1 \\
区域(2): \\
1976.11 .1
\end{tabular} & 1977. 1. 1 & 1977. 12. 10 & 1980.8.16 & 1995.2.10 \\
\hline
\end{tabular}

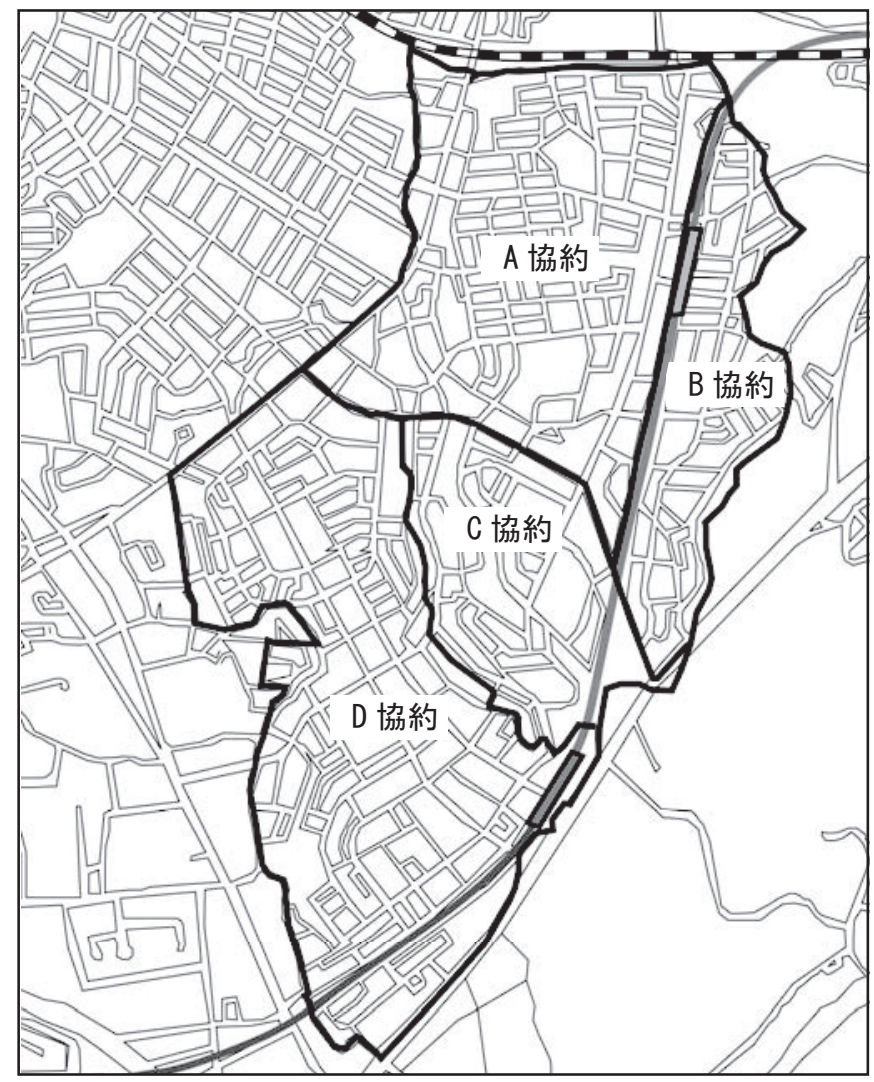

図 $1 \mathrm{~T}$ 地域における建築協約の効力が及ぶ区域 
協約は制定された。各建築協約の効力が及ぶ区域は、各自治会区域 である。そして、B 協約の効力発効日は 1977 年 1 月 1 日である。 C 協約の効力発効日は 1977 年 12 月 10 日である。そして、D 協約 の効力発効日は 1980 年 8 月 16 日である。一方、 $\mathrm{E}$ 会は、 $\mathrm{A}$ 協約に 反対した商業者注7) が中心となって設立された任意団体である。さ らに、商業者の働きかけにより、 $\mathrm{A} \sim \mathrm{C}$ 協約区域内に居住する地主 （以下、居住地主）も加入している。そして、 $\mathrm{E}$ 会は $\mathrm{E}$ 協約を制定 している注 8)。 $\mathrm{E}$ 協約の効力が及ぶ範囲は、 $\mathrm{A} \sim \mathrm{C}$ 協約区域に土地を 所有している会員である。そして、効力発効日は 1995 年 2 月 10 日 である。

\section{3-3. 建築協約を運用する自治会の設立と会員の構成}

T 地域における自治会の設立は、生活防衛を目的として、宅地分 譲時の新住民により行われた。 $\mathrm{T}$ 地域は、東急不動産による宅地分 譲以前、地主が $\mathrm{O}$ 町内会を形成していた。宅地分譲後、新住民が居 住を始めるものの、 $\mathrm{O}$ 町内会に加入していなかった。しかし、新住 民を中心として環境を守ろうとする運動が起こり、これを契機とし て、新住民のみにより 1971 年 1 月に A 自治会が設立された。一方、 $\mathrm{A}$ 自治会区域外の新住民は $\mathrm{O}$ 町内会に加入した。そして、O 町内会 区域で 1971 年夏に集合住宅問題が発生した注 9)。近隣の新住民は、 問題に対処するため自治会設立を求めた。もともと $\mathrm{O}$ 町内会では、 住民が増え寸ぎていたこともあった。そこで、O 町内会は、区域を 丁目毎に分離し、自治会を設立することを決定する。そして、B 自 治会、C 自治会、および、D 自治会が結成された。

$\mathrm{T}$ 地域の 4 自治会および任意団体 $\mathrm{E}$ 会の会員の属性は、設立経緯 により、(1)新住民中心、および、(2)新住民と地主の混成に分類でき る。表 4 は、 $\mathrm{A}$ 自治会から $\mathrm{E}$ 会における会員および会員外の属性の 傾向を示している。A 自治会は、設立の経緯から、宅地分譲時の新 住民中心の構成である。そのため、 $\mathrm{A}$ 自治会区域の地主は $\mathrm{A}$ 自治会 に加入していない。 $\mathrm{B}$ 自治会区域も宅地分諒時の新住民中心の構成 である。これは、居住地主が少なく不在地主が多いためである。一 方、C 自治会および D 自治会の区域では、もともと居住地主が多い。 $\mathrm{O}$ 町内会から分離独立した経緯から、宅地分讓時の新住民と居住地 主による構成である。 $\mathrm{E}$ 会は、商業者である新住民および居住地主 による構成である。なお、 $\mathrm{C}$ 自治会に加入する居住地主が $\mathrm{E}$ 会へ重 複加入している。

自治会への加入率の高さは、(1)地主の土地所有率の低さ、および、 (2)自治会設立における宅地分袞時の新住民と居住地主の取り込み、

表 4 各運営団体における会員および会員外の属性の傾向

\begin{tabular}{|c|c|c|c|c|c|c|}
\hline & & A自治会 & B自治会 & C自治会 & D自治会 & E会 \\
\hline \multirow{2}{*}{ 会員 } & 新住民 & 0 & 0 & 0 & 0 & 0 \\
\hline & 居住地主 & & & 0 & 0 & 0 \\
\hline \multirow{3}{*}{ 会員外 } & 新住民 & & & & & 0 \\
\hline & 居住地主 & 0 & & & & \\
\hline & 不在地主 & 0 & 0 & 0 & 0 & 0 \\
\hline
\end{tabular}

*2010年6月時点

表 5 各運営団体における会員数

\begin{tabular}{|c|c|c|c|c|c|}
\hline & A自治会 & B自治会 & C自治会 & D自治会 & E会 \\
\hline 会員数 & 750 & 515 & 400 & 1225 & 約50 \\
(加入率) & $($ 約70\%) & $(87 \%)$ & $(85 \%)$ & $(56 \%)$ & \\
\hline
\end{tabular}

$* 2010$ 年6月時点

*団体が自治会の場合、( )内に加入率
が影響している。地主は不動産経営のため集合住宅を建設する傾向 がある。そのため、地主の土地所有率が高いと集合住宅が増加する。 その集合住宅居住者は自治会加入に消極的な傾向がある。表 5 は、 $\mathrm{A}$ 自治会から $\mathrm{E}$ 会における会員数および加入率を示す。 $\mathrm{A}$ 自治会の 加入率は約 $70 \%$ である。東急不動産が 7 割を宅地分譲したものの、 地主が会員外であることが加入率の低さにつながっている。B 自治 会の加入率は $87 \%$ である。東急不動産が 7 割を宅地分譲するととも に不在地主が多いことが加入率の高さにつながっている。C 自治会 の加入率は $85 \%$ である。東急不動産が 7 割を宅地分譲し、さらに、 居住地主を取り込んだことが加入率の高さにつながっている。D 自 治会の加入率は $56 \%$ である。東急不動産が 3 割しか宅地分譲しなか った区域である。そのため、地主が開発する集合住宅に入居した新 住民が多い。入会率の低さは、彼らが自治会に未加入である影響が 大きい。 $\mathrm{E}$ 会は入会を希望する商業者である新住民および居住地主 で構成され、会員数は約 50 である。

\section{3-4. 3 章の小括}

本節では、 $\mathrm{T}$ 地域という同じ地勢にありながら各建築協約が区域 に固有の文脈の上で成立していることを確認した。 $\mathrm{T}$ 地域における 建築協約数は 5 であり、自治会による運用が 4 、任意団体による運 用が 1 である。自治会による建築協約の設立は、建築上のトラブル への対応という目的で共通している。ただし、各自治会を比較する と構成員および加入率に差がある。また、 $\mathrm{E}$ 協約は、 $\mathrm{A}$ 協約への反 対を契機として制定されている。そのため、 $\mathrm{A} \sim \mathrm{C}$ 協約の効力範囲 と $\mathrm{E}$ 協約の効力範囲が重複している。ただし、B 協約区域には居住 地主が少ない。また、 $\mathrm{C}$ 自治会加入者は $\mathrm{E}$ 会加入者でもある。その ため、 $\mathrm{A}$ 協約と $\mathrm{E}$ 協約が最も競合関係にあると考えられる。

\section{T地域における建築協約の比較}

\section{4-1. 建築協約におけるまちづくりの目標および規定項目}

建築協約が掲げるまちづくりの目標は、(1)分譲住宅地保全系、(2) 新開発誘導系、(3)環境・開発両立系に分類できる。表 6 は、各建築 協約が掲げるまちづくりの目標を示し、表 7 は、各建築協約の規定 項目を示している。 $\mathrm{A} \sim \mathrm{C}$ 協約では、「住環境維持」「迷惑がかから ない」がまちづくりの目標に掲げられている。また、「建築協定の締 結を望む」も掲げられており、規定項目は建築協定で規定される項 目を踏襲している。また、A 協約区域には建蔽率 60\%あるいは 80\% が含まれている注 10) にもかかわらず、A 協約の項目では建蔽率 $40 \%$ が明記されている。さらに、A 協約独自の規定に、庭の確保・駐車 場の制限がある。このように、 $\mathrm{A}$ 協約は $\mathrm{T}$ 地域で最も規定が厳しい 建築協約である。 $\mathrm{A} \sim \mathrm{C}$ 協約の区域は東急不動産による宅地分譲が 7

表 6 各建築協約が掲げるまちづくりの目標

\begin{tabular}{|c|c|c|c|c|c|}
\hline & A協約 & B協約 & C協約 & D協約 & E協約 \\
\hline 住環境維持 & $\mathrm{O}$ & $\mathrm{O}$ & $\mathrm{O}$ & 0 & $\mathrm{O}$ \\
\hline 迷惑がかからない & 0 & $\mathrm{O}$ & 0 & & \\
\hline 交通安全 & 0 & & & & \\
\hline $\begin{array}{l}\text { 騒音・大気污染のな } \\
\text { い静かな街 }\end{array}$ & 0 & & & & \\
\hline $\begin{array}{l}\text { 建築協定の締結を望 } \\
\text { む }\end{array}$ & 0 & 0 & O & & \\
\hline 防災 & & & & 0 & \\
\hline 公共施設の劣化防止 & & & & 0 & \\
\hline 生活の利便性 & & & & & 0 \\
\hline 活力 & & & & & 0 \\
\hline
\end{tabular}


表 7 各建築協約の規定項目

\begin{tabular}{|c|c|c|c|c|c|}
\hline & A協約 & B協約 & C協約 & D協約 & E協約 \\
\hline 用途 & \begin{tabular}{|l} 
原則、一戸 \\
建て専用住 \\
宅、風俗営 \\
業・遊戲 \\
場·工工場、 \\
共同住宅の \\
禁止
\end{tabular} & $\begin{array}{l}\text { 原則、一戸 } \\
\text { 建て専用住 } \\
\text { 宅 }\end{array}$ & $\begin{array}{l}\text { 原則、一戸 } \\
\text { 建て専用住 } \\
\text { 宅 }\end{array}$ & $\begin{array}{l}\text { 原則、一戸 } \\
\text { 建て尃用住 } \\
\text { 宅 }\end{array}$ & 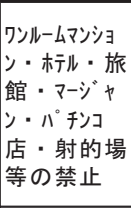 \\
\hline $\begin{array}{c}\text { 道路·隣地境 } \\
\text { 界からの壁面 } \\
\text { までの距離 }\end{array}$ & 1. $5 \mathrm{~m}$ 以上 & $\begin{array}{c}\text { 北側： } \\
1.5 \mathrm{~m} \text { 以上 } \\
\text { その他： } \\
1 \mathrm{~m} \text { 以上 }\end{array}$ & $1 \mathrm{~m}$ 以上 & 1. $2 \mathrm{~m}$ 以上 & $1 \mathrm{~m}$ 以上 \\
\hline 階数 & 2階以下 & 2階以下 & 2階以下 & 2階以下 & \\
\hline $\begin{array}{c}\text { 擁壁の增し積 } \\
\text { み禁止 }\end{array}$ & O & 0 & 0 & & 0 \\
\hline 1区画の面積 & $165 \mathrm{~m}^{2}$ 以上 & $165 \mathrm{~m}^{2}$ 以上 & $165 \mathrm{~m}^{2}$ 以上 & $165 \mathrm{~m}^{2}$ 以上 & \\
\hline $\begin{array}{l}\text { 上下水道・ガ } \\
\text { ス・污水処理 } \\
\text { 施設の完備 } \\
\end{array}$ & 0 & 0 & O & 0 & \\
\hline $\begin{array}{c}\text { 屋外設備の } \\
\text { 位置 }\end{array}$ & O & 0 & 0 & O & \\
\hline $\begin{array}{c}\text { 敷地の細分化 } \\
\text { 禁止 }\end{array}$ & 0 & 0 & 0 & & 0 \\
\hline 建物の高さ & 9m以下 & 9m以下 & $9 \mathrm{~m}$ 以下 & & \\
\hline 軒の高さ & 6. $5 \mathrm{~m}$ 以下 & 6. $5 \mathrm{~m}$ 以下 & 6. $5 \mathrm{~m}$ 以下 & & \\
\hline $\begin{array}{c}\text { 門・塀の形 } \\
\text { 状·構造·材 } \\
\text { 質の指定 } \\
\end{array}$ & O & 0 & 0 & & \\
\hline $\begin{array}{c}\text { 広告 - 看板の } \\
\text { 制限 }\end{array}$ & 0 & & & 0 & \\
\hline 建蔽率 & $40 \%$ & & & & \\
\hline 庭の確保 & 0 & & & & \\
\hline 駐車場の制限 & 0 & & & & \\
\hline $\begin{array}{c}\text { 地盤面の高さ } \\
\text { 変更禁止 }\end{array}$ & & & & 0 & 0 \\
\hline $\begin{array}{c}\text { 建築物の意匠 } \\
\text { 等 }\end{array}$ & & & & & $\begin{array}{c}\text { 落ち着いた } \\
\text { もの }\end{array}$ \\
\hline
\end{tabular}

割を占めていることもあり、建築協約の項目も分譲地における住環 境保全が重視されていると考えられる。そこで、 $\mathrm{A} \sim \mathrm{C}$ 協約は、分 譲住宅地保全系と呼ぶことができる。D 協約では、「住環境維持」 に加え、「防災」「公共施設の劣化防止」が掲げられている。地主の 土地所有が 7 割を占め、D 協約の項目も地主による開発が住環境破 壊や苂害につながらないことが重視されていると考えられる。そこ で、D 協約は、新開発誘導系と呼ぶことができる。これに対し、E 協約は、「住環境保全」と共に、「生活の利便性」「活力」が掲げられ ている。 $\mathrm{A} \sim \mathrm{C}$ 協約が、住環境と開発は背反すると考えるのに対し、 $\mathrm{E}$ 協約は住環境と開発が両立すると考えられている。規定項目も、 $\mathrm{A} \sim \mathrm{C}$ 協約と $\mathrm{E}$ 協約に共通寸るものと $\mathrm{A} \sim \mathrm{C}$ 協約では規定され $\mathrm{E}$ 協 約では規定されないものがある。そのため、 $\mathrm{E}$ 協約は、環境・開発両 立系と呼ぶことができる。

\section{4-2. 建築協約の効力が及ぶ時期および対象者}

建築協約は、(1)賛同していない者に対しても効力を及ぼすもの、 および、(2)賛同する者にのみ効力を及ぼすものに分類できる。表 8 は、各建築協約の効力が及ぶ時期および対象者を示している。 $\mathrm{A} \sim \mathrm{C}$ 協約は、現在および将来にわたり、区域内において居住する者、建 築物を建てる者、宅地造成を行う者、および、土地を所有する者に 効力が及ぶ。 D 協約は、現在および将来にわたり、区域内において 居住する者、建築物を建てる者、および、宅地造成を行う者に効力 が及ぶ。土地を所有する者が対象外なのは、D 協約が敷地の細分化 を禁止していないためと考える。このように、 A D 協約の効力は、 現在から将来にわたり協約区域内の全ての建築物および土地に及ん でいる。言いかえると、A〜D 協約は、建築協約に賛同していない
表 8 各建築協約の効力が及ぶ時期および対象者

\begin{tabular}{|c|c|c|c|c|c|c|c|}
\hline & \multicolumn{2}{|c|}{$\begin{array}{c}\text { 効力が及ぶ } \\
\text { 時期 }\end{array}$} & \multicolumn{5}{|c|}{ 効カが及ぶ対象者 } \\
\hline & 現在 & 将来 & $\begin{array}{c}\text { 協定区域 } \\
\text { 内におい } \\
\text { て居住す } \\
\text { る者 }\end{array}$ & \begin{tabular}{|l}
$\mid$ 劦定区域 \\
内におい \\
て建築物 \\
を建てる \\
者
\end{tabular} & $\begin{array}{c}\text { 協定区域 } \\
\text { 内におい } \\
\text { て宅地造 } \\
\text { 成を行う } \\
\text { 者 }\end{array}$ & \begin{tabular}{|c|} 
協定区域 \\
内におい \\
て土地を \\
所有する \\
者
\end{tabular} & $\begin{array}{c}\text { 協定区域 } \\
\text { 内におい } \\
\text { て土地を } \\
\text { 所有する } \\
\text { 会員 }\end{array}$ \\
\hline A協約 & 0 & 0 & 0 & 0 & 0 & 0 & \\
\hline B協約 & 0 & 0 & 0 & 0 & 0 & 0 & \\
\hline C協約 & 0 & 0 & 0 & 0 & 0 & 0 & \\
\hline D協約 & 0 & 0 & 0 & 0 & 0 & & \\
\hline E協約 & $\mathrm{O}$ & & & & & & $\mathrm{O}$ \\
\hline
\end{tabular}

者に対しても効力を及ぼそうとしている。これに対し、 $\mathrm{E}$ 協約の効 力は、現時点で建築協約に賛同する、協定区域内において土地を所 有する会員にのみに及んでいる注 11。

\section{4-3. 行政指導期における建築協約の運用}

A 協約が制定された 1976 年から 1990 年代中頃まで、町田市によ る行政指導の支援を受け建築協約は運用されていた。本研究では、 町田市により行政指導が行われていた時期を「行政指導期」と呼ぶ こととする。建築計画者が町田市建築指導課に事前相談に訪れると、 町田市建築指導課は、建築業者に対し建築協約委員会の承認印を鿓 ってくるよう指導した。そして、承認印がない建築計画については 建築確認申請を受け付けなかった。建築協約委員会による独自審査 の手順は、まず、建築協約委員会は建築計画者から連絡書および建 築図面（配置図、平面図、立面図）の受け取りに始まる。連絡書に は、(1)土地および家屋の面積、(2)後退距離、および、(3)地盤からの 建築の高さおよび軒の高さ、が記入される。 A〜 E 協約の委員は、 建築協約違反がないか独自に審查を行う。違反がない場合、承認印 を押す。違反がある場合、違反を指摘し計画変更を依頼する。さら に、B 自治会および $\mathrm{C}$ 自治会では、近隣住民注 ${ }^{12}$ ) が図面等を閲覽し、 問題がなければ承認印を押寸注 13 )。以上を終え、建築計画者は町田 市役所に建築確認申請を行い、町田市役所は建築確認を行う。

\section{4-4. 町田市による行政指導の効果}

町田市による行政指導の効果は非常に大きかったと考えられる。 表 9 は、行政指導期における行政指導の効果を記憶していた建築協 約委員のインタビュー調查における発話内容を示している。表 9 の

表 9 行政指導の効果に対する建築協約委員の評価

\begin{tabular}{|c|c|c|}
\hline \multicolumn{2}{|c|}{ 発話者 } & 発話内容 \\
\hline $\begin{array}{l}\text { B } \\
\text { 協 } \\
\text { 約 }\end{array}$ & b1 & 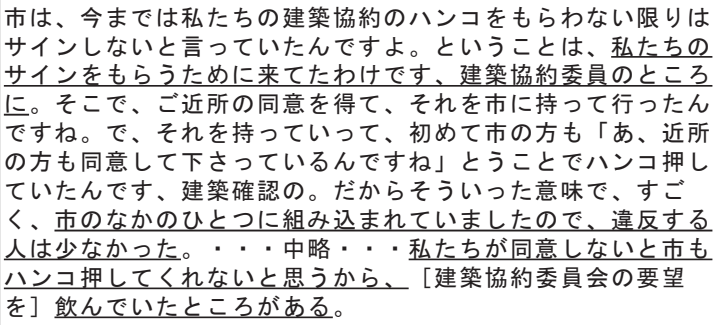 \\
\hline $\begin{array}{l}\text { D } \\
\text { 協 } \\
\text { 約 }\end{array}$ & d1 & 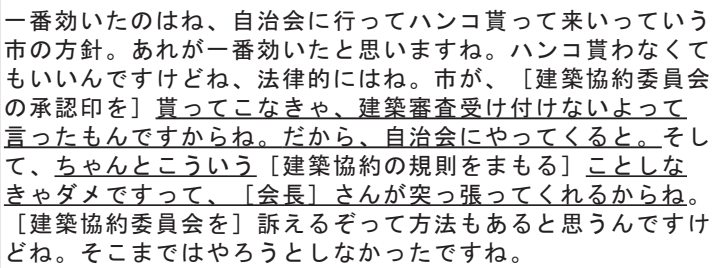 \\
\hline
\end{tabular}


下線部より、建築協約委員は、建築計画者が建築協約委員会の承認 印が貪えないと困ることを自覚していると思われる。そのため、建 築協約委員は、建築計画者に対し計画変更の要望を直接的に行って いた。また、建築計画者も計画変更に従ってきたと考えられる。

\section{4-5. 4 章の小括}

$\mathrm{T}$ 地域の建築協約は、分譲住宅地保全系、新開発誘導系、および、 環境・開発両立系に分類できる。さらに、建築協約は、賛同していな い者に対しても効力を及ぼすもの、および、賛同する者にのみ効力 を及ぼすものに分類できる。1976 年から 1990 年中頃まで、町田市 は行政指導において建築協約委員会の承認印がないと建築確認申請 を受け付けなかった。効果は非常に大きかったと考えられる。建築 協約委員は、建築計画者に対し計画変更の要望を直接的に行ってい た。また、建築計画者も計画変更に従ってきた。

\section{5. 建築計画者の把握および建築協約の遵守の困難化と地域住民によ る対応策}

\section{5-1．建築計画者の把握および建築協約の遵守の困難化}

(1)町田市における行政指導の効力の消失

行政手続法の制定により、町田市による行政指導の効果は失われ た。行政指導期における町田市による行政指導では、建築協約委員 会の承認印を貪えるまで建築確認申請を受け付けていなかった。こ れに対し、行政手続法制定後、町田市は、建築協約が存在している ことは通知するものの、建築協約委員会の承認印がない建築計画で あっても建築確認を行っている。これは、行政指導期において建築 協約委員からの要望が建築計画者に受け入れられや寸かったのに対 し、行政手続法制定後は受け入れられにくくなる可能性を示してい る。

(2)町田市における建築計画者を把握する困難さの増大

建築確認業務の民間開放および行政手続法の制定により、建築協 約委員会が区域内における建築計画を建築確認申請前に知ることが 困難になった。1998 年の建築確認業務の民間開放前では、町田市内 における建築確認申請は町田市で一括して受理していた。これに対 し、民間開放後、建築計画者は、指定確認検查機関に建築確認申請 し審査を受け確認済証の交付を受ける。そして、その後、指定確認 検查機関より確認済の報告が町田市に届くことになる。これは、民 間開放前は、町田市に情報提供を求めると、建築確認申請前に建築 協約委員が建築計画者を把握できたのに対し、民間開放後は、町田 市に情報提供を求めても、把握が困難になることを示している。表 10 は、各建築協約の適用区域における 2009 年度の建築確認済件数 を示している。協約区域の全てにおいて、指定確認検查機関による

表 10 各建築協約の適用区域における 2009 年度の建築確認済件数

\begin{tabular}{|c|c|c||c|}
\hline & $\begin{array}{c}\text { 町田市 } \\
\text { 建築指導課 }\end{array}$ & $\begin{array}{c}\text { 指定確認 } \\
\text { 検査機関 }\end{array}$ & $\begin{array}{c}\text { 建築確認済 } \\
\text { 件数の合計 }\end{array}$ \\
\hline A協定区域 & 10 & 21 & 31 \\
& $(32 \%)$ & $(68 \%)$ & $(100 \%)$ \\
\hline B協定区域 & 3 & 6 & 9 \\
\hline \multirow{2}{*}{ C協定区域 } & $(33 \%)$ & $(67 \%)$ & $(100 \%)$ \\
\hline D十協定区域 & 0 & 17 & 17 \\
& $(0 \%)$ & $(100 \%)$ & $(100 \%)$ \\
\hline 町田市全域 & $(11 \%)$ & 32 & 36 \\
& 506 & $(89 \%)$ & $(100 \%)$ \\
\hline
\end{tabular}

建築確認済件数が 7 割以上を占めており、建築計画者の把握の困難 性が高まっていることを裏付けている。さらに、行政指導期におけ る町田市は、建築計画者に承認印を貫うよう指導した。これに対し、 行政手続法制定後、町田市は建築計画者に対し建築協約の存在を通 知するのみである。そのため、建築協約委員会と連絡をとることは 建築計画者の裁量に委㸚られている。

\section{5-2. 建築計画者を把握する取り組み}

$A \sim D$ 協約の委員会は、工事開始前あるいは建築確認申請前に建 築計画者を把握するための独自の取り組みを行っている。一方、 $\mathrm{E}$ 協約の規定項目は必ずしも厳格ではない。そのため、 $\mathrm{E}$ 会は、協約 違反は少ないと考えており、現在、独自審查を行っていない注 14$) 。$

\section{(1) 工事開始前における建築計画者の把握}

建築協約への協力を依頼し、協力を引き出すには、建築協約委員 会が工事開始前に建築計画者を把握できることが重要である。工事 開始前における建築協約への協力の依頼であれば、工事開始後と比 較して、協力を引き出せる可能性は高まる。そこで、A 協約の委員 は、建築確認審査済みの物件の有無についての町田市役所への問い 合わせを $2 \sim 3$ カ月に 1 回のペースで行っている。指定確認検査機 関による建築確認審查を通った物件の情報も町田市役所に集約され る。そのため、既に建築確認審査が完了した物件ではあるものの、 情報の入手は容易である。ただし、問い合わせが遅れると、建築計 画者の把握が工事開始後なってしまう恐れがある。

\section{(2) 工事開始前における建築計画者の把握および建築確認申請前に}

\section{おける建築行為の予兆の把握}

建築協約へのより多くの協力を引き出すには、建築協約委員会が 建築確認申請前に建築行為の予兆を把握できることが重要である。 建築確認申請前における建築協約への協力の依頼であれば、工事開 始前と比較して、協力を引き出せる可能性は高まる。B 協約の区域 では、建築計画者を把握する仕組みを住民全体の協力を得て発達さ せている。まず、B 協約の区域は道路で囲われた 40 ブロックで成 り立つっして、自治会役員が各ブロックから 1 名ずつ選出される。 選出された各役員は自らのブロックを担当し、(1)引っ越し、(2)建物 の解体、(3)地鎮祭、が発生すると、委員に報告する。これは、自治 会加入率 $87 \%$ という組織力に支えられている。さらに、建築協約委 員は、(4)新聞広告内の売地の情報を収集する。(1)引つ越し、および、 (4)売地情報は、建築確認申請前における建築計画の予兆を知ること ができる。ただし、必ず買い手を把握できるとは限らない。また、 (3)地鎮祭は、工事開始前における建築計画者を把握する確率を高め る。(2)建物の解体は、建築確認申請前あるいは工事開始前の両方の 可能性を含む。

\section{（3）建築確認申請前における建築計画者の把握}

指定確認検査機関が建築計画者へ建築協約の存在を通知できれば、 建築協約委員会が建築確認申請前に建築計画者を把握できる確率が 高まる。2008 年に C 協約の委員は、指定確認検查機関の事務所へ 出向き、建築協約の内容を説明し、協約区域における建築計画者に 建築協約が存在することを通知し、建築協約委員に連絡するよう話 すことを依頼している。

建築協約を通知するよう依頼された指定確認検查機関の対応は、 建築協約を通知する場合と通知しない場合に分かれる。C 協約委員 が建築協約の存在を通知するよう依頼した 2 社における建築協約の 
対応を示す (表 11 参照)。I 社は、C 協約区域における建築計画者 に対して、建築協約の存在を通知している。一方、II 社は、C 協約 区域において建築協約があることを通知していない。ただし、原則、 建築協定等の有無については所管の特定行政庁に問い合わすよう話 している。指定確認検查機関が建築協約の存在を建築計画者へ通知 する場合、建築協約委員に連絡するかが建築計画者に委ねられるこ とになる。これに対し、指定確認検查機関が建築協約の有無を町田 市役所に問い合わせるように話す場合、町田市役所に問い合わせる か、さらにその後、建築協約委員に連絡するかが建築計画者に委㸚 られることになる。

指定確認検查機関における建築協約の対応の差は、(1)受付所在地 および(2)審查担当者の入れ替わりに起因すると考える。まず、一見 寸ると、業務区域が広いことが指定確認検查機関における建築協約 の存在を通知する作業を困難にさせていると考えられる。これに対 し、本調査では、II 社と比心゙、業務区域が広い I 社が建築協約の存 在を建築計画者へ通知していることを確認できた。I 社の特徵は、 町田市に受付所在地があることである。受付所在地が町田市にある ことが、I 社の建築協約に対する協力を引き出している可能性があ ると考える。また、建築協約の存在の通知は、建築協約委員より依 頼を受けた審査担当者の裁量で行われている。そのため、担当者の 入れ替わりに応じて建築協約に関する情報が社内で失われる可能性 があることを確認できた。

表 11 指定確認検查機関における建築協約の対応

\begin{tabular}{|c|c|c|c|}
\hline & 協約への対応 & 業務区域 & 受け付け所在地 \\
\hline I社 & $\begin{array}{l}\text { 建築協約があることを業者にお } \\
\text { 知らせ }\end{array}$ & $\begin{array}{l}\text { 埼玉県, 千葉県, 東京 } \\
\text { 都(島しょ部を除く)，お } \\
\text { よび, 神奈川県の全域 }\end{array}$ & $\begin{array}{l}\text { 東京都渋谷区 } \\
\text { 東京都中央区 } \\
\text { 東京都町市 }\end{array}$ \\
\hline III社 & $\begin{array}{l}\text { 建築協約に関するお知らせはし } \\
\text { ていない, 建築協定等の有無は } \\
\text { 所管の特定行政庁に問い合わ } \\
\text { せるよう話す }\end{array}$ & $\begin{array}{l}\text { 東京都(6区、および、 } \\
\text { 町田市を含む10市), お } \\
\text { よび, 神奈川県の全域 }\end{array}$ & $\begin{array}{l}\text { 神奈川県相模原市 } \\
\text { 神奈川県川崎市 } \\
\text { 神奈川県横浜市 }\end{array}$ \\
\hline
\end{tabular}

\section{（4）建築確認申請前に建築計画者を把握する取り組みの効果}

建築確認申請前に建築計画者を把握することを目的とした建築協 約委員会の取り組みには効果が表れている。町田市への問い合わせ を行う A 協約では、建築確認申請前に図面等を受け取った件数は 22 あり、2009 年度の建築確認済数に占める割合は $71 \%$ ある。一 方、見逃し件数は 10 である。ただし、A 協約の委員会は、必ずし も見逃し件数を正確に把握できていない。見逃した物件の内、明ら かに建築協約違反であれば、建築計画者に図面等の提出を依頼して いる。建築確認申請前に建築行為の予兆の把握を行う B 協約では、 建築確認申請前に図面等を受け取った件数は 9 あり、2009 年度の 建築確認済数に占める割合は $100 \%$ あ゙あ。指定確認検查機関に協 力をお願いしている C 協約では、建築確認申請前に委員会が図面等 を受け取った件数は 15 あり、2009 年度の建築確認済数に占める割 合は $87 \%$ でる。さらに、建築協約委員会は、建築確認申請前に図 面等を受け取れなかった 2 件についても、工事開始前に建築計画者 を把握し、図面等の提出を依頼している。取り組みを行っていない $\mathrm{D}$ 協約では、建築確認申請前に図面等を受け取った件数は 15 あり、 2009 年度の建築確認済数に占める割合は $43 \%$ あ゙あ。一方、見逃 し件数は 21 である。D 協約の委員会は、必ずしも見逃し件数を正 確に把握できていない。また、建築確認済であれば、建築計画者に
図面等の提出を求めていない。なお、各協約区域で実施されている 取り組みの情報は、 $\mathrm{A} \sim \mathrm{D}$ 協約の委員会相互で共有されていないこ とを確認している。

$\mathrm{A} \sim \mathrm{D}$ 協約の全てにおいて、建築協約委員会が建築確認申請前に 図面等を受け取った件数は、町田市建築指導課による建築審查済件 数 (表 10 参照) より多い。これは、活動が継続的に行われている ことから、建築協約の存在が住民および業者に浸透していること、 また、建築確認申請に指定確認検查機関を利用寸る場合も、事前相 談は町田市で行っていることが理由として考えられる。

\section{5-3. 規定項目に対する遵守者増加の取り組み}

$\mathrm{A} \sim \mathrm{D}$ 協約の委員会は、建築協約を遵守寸る建築計画者が増加す るよう取り組んでいる。一方、独自審查を行っていない $\mathrm{E}$ 協約では 取り組まれていない。

\section{(1) 要望の効力を高めるエ夫}

建築協約委員会は、建築計画者が要望を受け入れるよう要望の方 法を工夫している。行政指導期であれば、建築協約委員は要望を示 すのみで良かった。これに対し、行政手続法の制定後、建築計画者 から協力を引き出せる方法の仕組みが必要となる。表 12 は、説明 の方法の工夫について建築協約委員の発話内容を示している。 $\mathrm{A}$ 協 約の委員は、「日照権が邪魔される」と近隣住民の権利侵害を訴えて いる（表 12 の発話者 $\mathrm{a} 1$ の下線部参照）。B 協約の委員は、他者も 協力していることを提示することで建築計画者の協力を引き出そう としている。また、「景観」「防災」など全員の協力が必要な公共財 の存在を指摘している。（表 12 の発話者 b1 の下線部参照） C 協約 の委員は、「静かで環境がいい」ことが建築協約によって実現してい ることを説いている (表 12 の発話者 $\mathrm{c} 1$ の下線部参照)。D 協約の 委員は、居住者が不利益を継続的に受け、その影響が建物を建てる

表 12 説明の方法の工夫に関する建築協約委員の発話内容

\begin{tabular}{|c|c|c|}
\hline \multicolumn{2}{|c|}{ 発話者 } & 発話内容 \\
\hline $\begin{array}{c}\text { A } \\
\text { 協 } \\
\text { 約 }\end{array}$ & a1 & $\begin{array}{l}\text { 大型の分譲マンションが建ったことがあってね、ここに住んで } \\
\text { いる人たちの照権が問題になっでっここですね、ちょうど、 } \\
\text { [マンションの陰が]ひっかているんですよね。これで旦 } \\
\text { 照権が邪魔される、と。 }\end{array}$ \\
\hline $\begin{array}{l}\text { B } \\
\text { 協 } \\
\text { 約 }\end{array}$ & b1 & 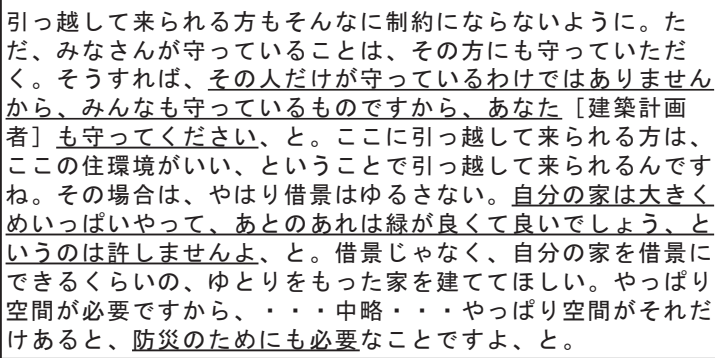 \\
\hline $\begin{array}{c}\text { C } \\
\text { 協 } \\
\text { 約 }\end{array}$ & $\mathrm{c} 1$ & 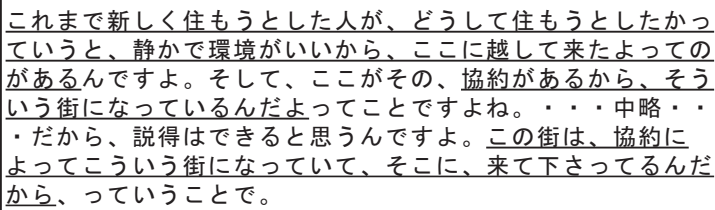 \\
\hline $\begin{array}{c}\text { D } \\
\text { 協 }\end{array}$ & $\mathrm{d} 2$ & $\begin{array}{l}\text { 買って住む人のことを考えて、まわりのことをね、考えた方が } \\
\text { いいんじやないですかって。そうしないと、企業自体のイメー } \\
\text { ジ自体も悪くなるし、買った人は騙されたってなって、うらむ } \\
\text { ようになるだろうし。。 }\end{array}$ \\
\hline 約 & d1 & 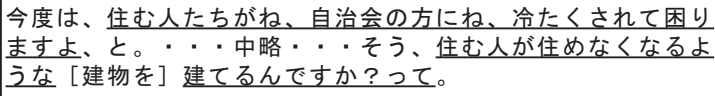 \\
\hline
\end{tabular}


業者にも及ぶことを説いている（表 12 の発話者 $\mathrm{d} 1$ および $\mathrm{d} 2$ の下 線部参照)。

2009 年度における各建築協約に対する違反は、建築協約委員会に よる建築計画者に対する説得の効果もあり一件も発生していない。 ただし、A 協約では、直近で 2005 年に建築協約違反が発生してい る。この事例では、建築確認申請前に連絡がなく、工事開始後に建 築協約委員会が計画の存在を発見した。建築計画者に対し内容証明 を送付したものの協約遵守には至らなかった。また、B 協約では、 直近で 2004 年に建築協約違反が発生している。この事例では、建 築確認申請前に連絡がなく、自治会役員が建築確認申請前に計画を 発見した。建築協約委員会の説得にもかかわらず工事が開始された ので、自治会は反対運動を実施した。しかし、協約遵守には至らな かった。説得の効果は大きいものの、完全ではない。

\section{(2) 町田市による建築計画者との事前協議の実効性}

行政が建築協約の規定内容について業者と事前協議をできれば、 規定内容は建築計画者により遵守される可能性はより高まる。C 協 約では、町田市住みよい街づくり条例（2004 年施行）に基づく「地 区まちづくりプラン」の策定を進めている。「地区まちづくりプラン」 において建築協約の規定項目に順じた「地区まちづくり計画」を策 定し、適用区域が町田市により「街づくり推進地区」に指定される と、建築計画者は建築行為等に着手する 30 日前に町田市に届出を 行い、事前協議を受けることになる。さらに、届出を行う前に、地 区住民に対し、「地区街づくりプラン」に指定された事項や計画内容 を示した標識を設置しなければいけない。ただし、「地区街づくり計 画」の策定には区域内住民等の 3 分の 2 以上の合意が必要となる。 表 13 は、「地区街づくり計画」策定の効果についての C 協約の委員 による発話内容を示している。建築協約委員会からの要望には限界 があり、町田市と建築計画者との事前協議であれば実効性が高いと 評価している。

表 13 「地区街づくり計画」策定の効果に関する建築協約委員の 発話内容

\begin{tabular}{|c|l|l|}
\hline \multicolumn{2}{|c|}{ 発話者 } & \multicolumn{1}{|c|}{ 発話内容 } \\
\hline$c$ & & $\begin{array}{l}\text { 協約で対処するのが行き詰っているわけですから、やっぱり、 } \\
\text { 協 } \\
\text { 約 }\end{array}$ \\
\hline
\end{tabular}

\section{5-4. 取り組みを実施できる条件}

行政手続法の制定後および建築確認業務の民間開放後における各 建築協約委員会による取り組みの展開は異なる。そして、取り組み の差は、(1)建築協約違反の発生および住環境破壊の可能性に対する 認識、(2)建築計画者の利用頻度の高い指定確認検查機関の情報、お よび、(3)合意コストに対する評価が影響すると考えられる。

\section{(1) 建築協約違反の発生および住環境破壊の可能性に対する認識}

建築確認申請前に建築計画者を把握する取り組み、および、「地区 街づくり計画」制定の取り組みは、建築協約違反が発生し住環境破 壊の可能性が大きいと建築協約委員が認識することと関わりがある と考えられる。表 14 は、建築協約違反の発生および住環境破壊に 関する建築協約委員の発話内容を示している。取り組みが行われて いる B 協約および C 協約の委員は、住環境の破壊を危惧している(表 14 の発話者 b1 および c2 の下線部参照)。これに対し、取り組みが
行われていない $\mathrm{A}$ 協約および D 協約の委員は、建築協約違反があま り発生しないと考えている（表 14 の発話者 $\mathrm{a} 1$ および $\mathrm{d} 2$ の下線部 参照)。

表 14 建築協約違反の発生および住環境破壊に関する建築協約委 員の発話内容

\begin{tabular}{|c|c|c|}
\hline \multicolumn{2}{|c|}{ 発話者 } & 発話内容 \\
\hline $\begin{array}{l}\text { A } \\
\text { 協 } \\
\text { 約 }\end{array}$ & a1 & 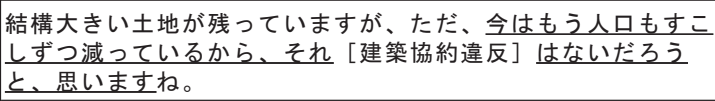 \\
\hline $\begin{array}{l}\text { B } \\
\text { 協 } \\
\text { 約 }\end{array}$ & b1 & 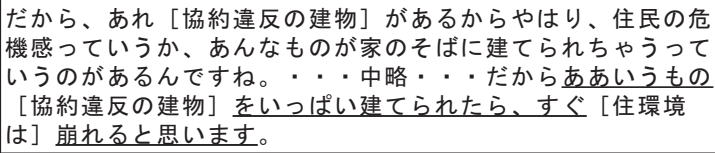 \\
\hline $\begin{array}{l}c \\
\text { 協 } \\
\text { 約 }\end{array}$ & $\mathrm{c} 1$ & 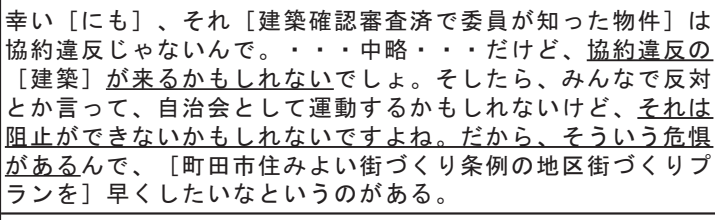 \\
\hline $\begin{array}{l}\text { D } \\
\text { 協 } \\
\text { 約 }\end{array}$ & d3 & 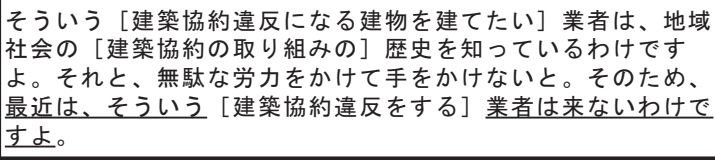 \\
\hline
\end{tabular}

\section{（2）建築計画者の利用頻度の高い指定確認検査機関に関する情報}

指定確認検查機関に対寸る働きかけは、協約区域内における建築 計画者の利用頻度が高い指定確認検査機関を知ることと関わりがあ ると考えられる。表 15 は、指定確認検査機関に関する建築協約委 員の発話内容を示している。町田市から情報を得た C 協約の委員は、 建築計画者の利用頻度が高い 2 社に対し協力を依頼している（表 15 の発話者 $\mathrm{c} 1$ の下線部参照)。これに対し、他の建築協約委員は情報 を得ていない。そのため、指定確認検査機関に働きかけようにも会 社が分からない (表 15 の発話者 b1 の下線部参照)。また、指定確 認検査機関に働きかけを考える場合、全国の指定確認検查機関が対 象となる（表 15 の発話者 $\mathrm{a} 1$ および $\mathrm{d} 2$ の下線部参照)。そのため、 働きかける主観的コストが大きくなっていると考えられる。

表 15 指定確認検查機関に関する建築協約委員の発話内容

\begin{tabular}{|c|c|c|}
\hline \multicolumn{2}{|c|}{ 発話者 } & 発話内容 \\
\hline $\begin{array}{l}\text { A } \\
\text { 協 } \\
\text { 約 }\end{array}$ & a1 & 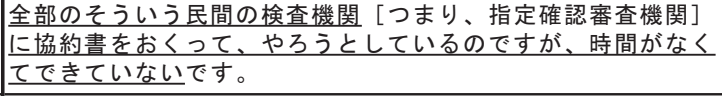 \\
\hline $\begin{array}{l}\text { B } \\
\text { 協 } \\
\text { 約 }\end{array}$ & b1 & 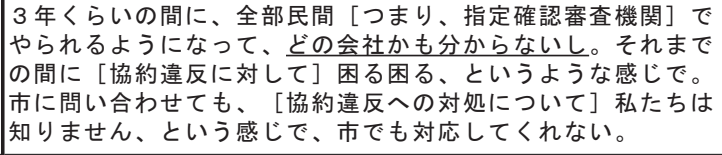 \\
\hline $\begin{array}{l}C \\
\text { 協 } \\
\text { 約 }\end{array}$ & c1 & 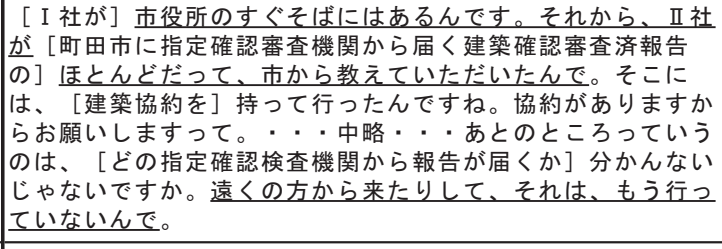 \\
\hline $\begin{array}{l}\text { D } \\
\text { 協 } \\
\text { 約 }\end{array}$ & d2 & 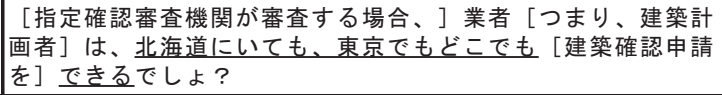 \\
\hline
\end{tabular}
[ ] 内は筆者が加筆修正 


\section{（3）地区街づくり計画制定に必要な合意コストに対する評価}

「地区街づくり計画」制定への取り組みは、協約区域内において 合意を作ることが出来ると建築協約委員が評価していることと関わ りがあると考えられる。表 16 は、合意に関する建築協約委員の発 話内容を示している。新住民と地主で自治会を作る C 協約の委員は、 話し合いの困難さを実感しつつも、継続する中で互いの理解が深ま ると考えている (表 16 の発話者 $\mathrm{c} 1$ の下線部参照)。これに対し、 新住民のみで自治会を作り $\mathrm{E}$ 会と競合する $\mathrm{A}$ 協約の委員は合意の難 しさを表明している（表 16 の発話者 a1の下線部参照）。新住民で 自治会を作り不在地主が多いB協約の委員は不在地主との合意の困 難性を表明している（表 16 の発話者 b1 および b2 の下線部参照）。 さらに、新住民と多くの地主で自治会を作る D 協約の委員は、建築 協約制定後も地主の潜在的反対があり、そもそも建築協約を変更し ようと寸ると建築協約の失効につながる可能性を心配している（表 16 の発話者 $\mathrm{d} 2$ の下線部参照)。

\section{表 16 合意に関する建築協約委員の発話内容}

\begin{tabular}{|c|c|c|}
\hline \multicolumn{2}{|c|}{ 発話者 } & 発話内容 \\
\hline $\begin{array}{c}\text { A } \\
\text { 協 } \\
\text { 約 }\end{array}$ & a1 & 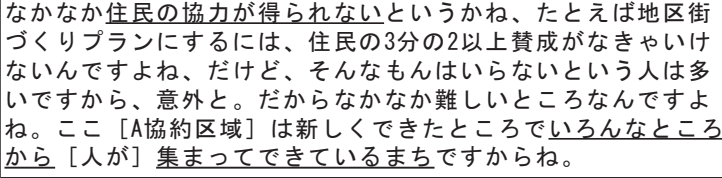 \\
\hline \multirow{2}{*}{\begin{tabular}{l|l} 
B \\
協 \\
約
\end{tabular}} & b2 & 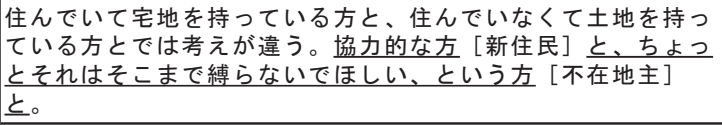 \\
\hline & b1 & 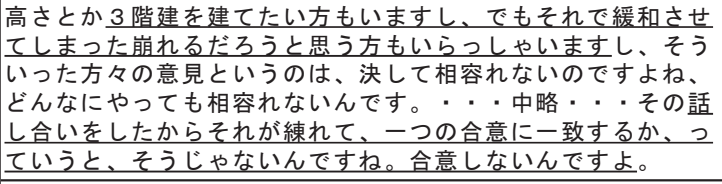 \\
\hline \begin{tabular}{c|c}
$C$ \\
協 \\
約
\end{tabular} & c1 & 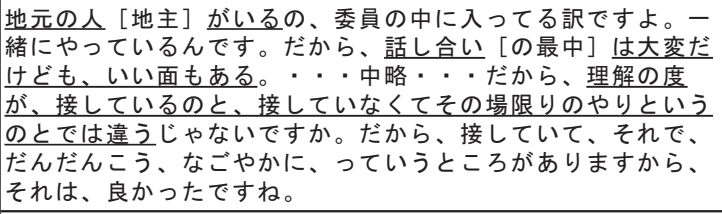 \\
\hline \multirow{2}{*}{$\begin{array}{l}\text { D } \\
\text { 協 } \\
\text { 約 }\end{array}$} & \multirow[t]{2}{*}{ d2 } & 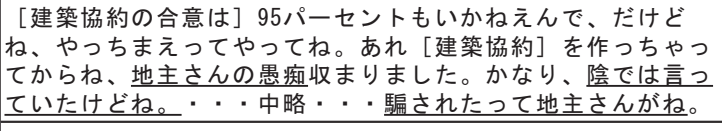 \\
\hline & & 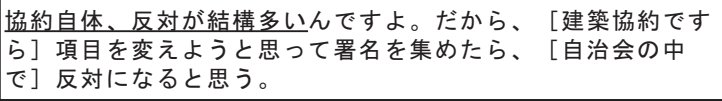 \\
\hline
\end{tabular}

\section{5-5. 5 章の小括}

行政手続法の制定および建築確認業務の民間開放は、行政指導期 における建築協約の実効性を消失させた。ただし、建築協約委員会 は実効性を高める取り組みを工夫してきた。まず、要望の表現方法 を工夫することで、建築計画者から建築協約への協力を多く引き出 すことに成功している。また、工事開始前および建築確認申請前に 要望できるよう、建築計画者を早めに把握する取り組みを行ってい る。さらに、規定項目をより厳守に近づけるため町田市による事前 協議の導入に取り組んでいる。ただし、取り組みの実施には差が見 られる。建築協約委員会が取り組みを実施する条件は、(1)建築協約 違反の発生および住環境破壊の可能性が大きいと認識されること、
(2)建築計画者の利用頻度の高い指定確認検查機関の情報を入手でき ること、および、(3)合意にかかるコストが低いこと、を確認した。

\section{6. まとめ}

行政指導期において行政指導を伴う建築協約の実効性は非常に高 かった。町田市による行政指導では、建築計画者は、建築協約委員 会の承認印を貪えないと建築確認申請を受け付けて貪えなかった。 そのため、建築協約委員会は建築協約の遵守を直接的に要望し、建 築計画者も従ってきた。しかし、行政手続法の制定および建築確認 業務の民間開放により、建築協約は後ろ盾を失った。そこで、各自 治会は、建築協約の実効性を高めるための取り組みを実施してきた。

住環境保全を目的とした自主ルールの実効性を高める住民組織の 取り組みは、1)建築計画者から協力を引き出すもの、および、2)建 築計画者を把握するものに分類できる。

建築計画者から協力を引き出す取り組みの内、最も実効性が高い 取り組みは、町田市住みよい街づくり条例に基づく「地区まちづく り計画」の策定である。これにより、規定項目の遵守が行政による 事前協議で実現可能となる。ただし、策定に必要な条件は、区域内 住民等の 3 分の 2 以上の合意であり、合意形成に取り組んでいるの は、 $\mathrm{T}$ 地域において $\mathrm{C}$ 自治会のみである。 $\mathrm{C}$ 自治会は、東急不動産 による宅地分譲が区域の 7 割と高く、また、自治会設立時のきっか けが $\mathrm{O}$ 町内会からの分離独立のため、新住民と地主で組織されると いう好条件が重なった。これに対し、他の建築協約では、合意形成 の条件は㛜しい。ただし、建築協約委員会による建築計画者への要 望でも建築計画者から協力を引き出寸実効性は充分に高い。直接的 に要望を伝えるのではなく、近隣住民の権利侵害、他者も協力して いること、公共財の存在、良好な住環境は建築協約のおかげである こと、および、居住者が受けた不利益の影響が業者にも返ってくる ことを伝えるというように、硬軟織り交ぜての説得が効果的である。 建築計画者への要望が実効的であるためには、工事開始前および 建築確認申請前に建築計画者を把握できるかが課題である。まず、 工事開始前に建築計画者を把握する取り組みには、町田市役所への 定期的な問い合わせ、および、自治会役員による日常的な監視があ る。町田市への定期的な問い合わせは、取り組みにかかるコストが 少なく済むものの、建築行為者を見逃してしまう可能性もある。一 方、自治会役員による日常的な監視の実効性は高い。ただし、これ は、B 自治会のように自治会加入率が高いことが必要である。つづ いて、建築確認申請前に建築計画の予兆を把握する取り組みには、 建築協約委員による売地情報の収集がある。売地情報の収集は新聞 広告の收集で実施可能であるが、買い手までは把握はできない。最 後に、建築確認申請前に建築計画者を把握する取り組みには、指定 確認検査機関への依頼がある。指定確認検査機関の協力が得られれ ば、建築計画者に建築協約の存在を通知することができる。ただし、 指定確認検查機関では、担当者の入れ替わりに応じて建築協約に関 する情報が社内で失われる可能性がある。そのため、指定確認検查 機関からの継続的な協力を得るために定期的な依頼が必要となる。

建築協約委員会が取り組みを実施する条件には、1）住環境の破 壊に対する危機意識、および、2）実施にかかるコストに分類でき る。まず、住環境が守れなくなると認識している B 協約および $\mathrm{C}$ 協 約の委員は、たまに発生する違反に注目し、危機意識を高める傾向 
がみられる。これに対し、A 協約および D 協約の委員は、ほとんど を占める協約遵守の事例に注目し、安心している傾向が見られる。 取り組みの実施は地元住民が自ら選択するものであり、介入は望ま しくないものの、建築協約違反の発生確率、および、違反の蓄積に よる悪影響等、将来予測に必要な情報提供は必要と考えられる。次 に、一般に、実効性が高い取り組みであるほど、実施（あるいは実 現）にかかるコストは大きい。自治会役員による日常的な監視、お よび、地区まちづくり計画」策定は実効性が高いものの、自治会内 の協力および区域内住民等の合意が必要である。これは、自治会員 および会員外の構成、および、自治会加入率に依存している。その ため、粘り強く時間をかけて、新住民、居住地主、および、不在地 主を組織化することが求められる。つづいて、指定確認検查機関へ の依頼は、依頼先を増やすと実効性は高まるがコストも増加する。 ただし、建築計画者による利用頻度が指定確認検查機関ごとで異な る。そのため、実効性を高めつつコストを抑えるには、利用される 頻度が高い指定確認検查機関の情報が不可欠である。そのため、行 政からの情報提供が必要と考える。

本研究では、自主ルールの実効性を高める取り組みの実施条件と して建築協約委員の心理的要因が確認できた。そこで、今後は心理 学分野からの検討も必要となると考える。

\section{謝辞}

本研究は、平成 21-22 年度科研費 (21730406)の研究助成を受け実施 したものである。また、インタビュー調査に際しては、町田市 $\mathrm{T}$ 地 域の建築協約委員、町田市役所建築指導課、および、指定確認検查 機関の皆さまより多大な協力を得ている。記してお礼申し上げます。

\section{注}

注 1）行政手続法では、行政指導があくまでも相手方の協力によってのみ実 現されること (同法第三十二条)、そして、申請の取り下げまたは内容の変 更を求める行政指導にあっては、申請者が行政指導に従う意思がないこと を表明したにもかかわらず、行政指導を継続し申請者の権利の行使を妨げ てはならないこと (同法三十三条)、が明記されている。

注 2) 詳しくは、鈴木(文献 10)参照。

注 3）以下の理由より、T 地域における建築協約は、行政指導による支援を 前提とした自主ルールの傾向が強いと考えられる。(1) T 地域を区域とする $\mathrm{A} \sim \mathrm{D}$ 協約は、最も初期に制定された建築協約であること（詳しくは、本 論文 3-2 節参照)。(2) A D 協約は、1993 年の行政手続法の制定、および、 1998 年の建築確認業務の民間開放前に制定されていること。

注 4) 各建築協約で委員会の名称は異なる。本研究では、運用を行う団体で あれば「建築協約委員会」と統一して呼ぶこととする。

注 5） C 協約の委員が建築計画者への建築協約の通知を依頼した指定確認検 查機関である。

注 6) 詳しくは、東京急行電鉄株式会社(文献 11)参照。

注 7）商業者は、近隣商業地域あるいは第二種中高層住居専用地域に対して、 厳しい規定である A 協約を適用することに反対した。

注 8）同一の地域に建築協約が 2 つある場合、行政はどちらか一方の建築協 約にのみに協力することはできない。 $\mathrm{E}$ 協約は、 $\mathrm{A} \sim \mathrm{C}$ 協約における行政指 導を相殺する効果を狙ったと考えられる。

注 9） C 自治会結成後、反対運動が起きる。結果、集合住宅は中止された。 詳しくは、鈴木(文献 10)参照。

注10）各建築協約の区域に含まれる用途地域，建蔽率，容積率，高度地区・
防火地域あるいは準防火地域を下表に示す。

表 T 地域の各建築協約区域に含まれる用途地域，建蔽率，容積率，高 度地区・防火地域あるいは準防火地域

\begin{tabular}{|c|c|c|c|c|c|c|}
\hline 用途地域名 & 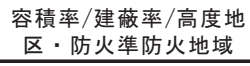 & $\begin{array}{c}\text { A } \\
\text { 協約 } \\
\end{array}$ & \begin{tabular}{|c|} 
B \\
協約 \\
\end{tabular} & \begin{tabular}{|c|} 
\\
協約 \\
\end{tabular} & $\begin{array}{c}D \\
\text { 協約 }\end{array}$ & \begin{tabular}{|c}
$E$ \\
協約
\end{tabular} \\
\hline \multirow{2}{*}{$\begin{array}{c}\text { 第一種低層住居 } \\
\text { 専用地域 }\end{array}$} & 80/40/I ·無 & 0 & 0 & 0 & 0 & 0 \\
\hline & 100/50/I · 無 & & & 0 & $\mathrm{O}$ & $\mathrm{O}$ \\
\hline \multirow{2}{*}{$\begin{array}{c}\text { 第一種中高層住居 } \\
\text { 専用域 }\end{array}$} & 100/50/31 II ·準 & & 0 & & 0 & \\
\hline & 200/60/31 II ·準 & & 0 & & 0 & \\
\hline \multirow{3}{*}{$\begin{array}{c}\text { 第二種中高層住居 } \\
\text { 専用地域 }\end{array}$} & 150/60/31 II · 準 & 0 & 0 & & 0 & 0 \\
\hline & 150/50/31 II · 準 & & & & & 0 \\
\hline & 200/60/31 II · 準 & & & & & 0 \\
\hline 準住居地域 & 200/60/31 II ·準 & & & & & 0 \\
\hline \multirow{2}{*}{ 近隣商業地域 } & 200/80/II ·準 & 0 & 0 & 0 & 0 & \\
\hline & 300/80/III ·準 & & & & & 0 \\
\hline
\end{tabular}

注11）中井（文献 12）は、自主ルールを「憲章型」および「契約型」に分類 する。建築協約に賛同していない者に対しても効力を及ぼすものは「憲章 型」に、賛同する者にの夕効力を及ぼすものは「契約型」に対応すると考 える。詳しくは、中井 (文献 12) 参照。

注12）近隣とは、建築が計画されている敷地の向こう三軒両隣にあたる住民 である。

注13）住民より問題が指摘された場合、原則、建築計画者と住民との話し合 いで解決が図られる。しかし、解決できない場合、建築協約委員が仲裁に 入ることがある。

注14）行政手続法の制定により、建築協約を支援する行政指導の効果は減少 した。そのため、必ずしも $\mathrm{A} \sim \mathrm{C}$ 協約における行政指導の効果を相殺する 必要がなくなったことも、現在、 $\mathrm{E}$ 会が独自審査を実施していない理由と 考えられる。

\section{参考文献}

1）中井検裕：土地利用規制主要としての協定の実態と有効性に関する研究, 住宅総合研究財団研究年報, No.23, pp.117-125, 1996.

2）乾康代・梶浦恒男：住環境管理を目的とした自主協定に関する事例研究一 一関西都市圈における自主協定運営過程と行政の支援，日本都市計画学会 都市計画論文集, No.36, pp.523-528, 2001.

3）熊谷かな子・野澤千絵・小泉秀樹・大方潤一郎：住民提案型地区まちづく り計画による住環境の管理・運営に関する研究一世田谷区まちづくり条例 を事例としてー, No.37, pp.391-396, 2002.

4）堂免隆浩・坂野達郎・中野章洋：田園調布地区に戈ける街並夕崩壊の社会 的ジレンマ性と違反行為をコントロールする仕組みに関する研究，日本都 市計画学会都市計画論文集, No.39-1, pp.41-49, 2004.

5）岩橋浩文：居住環境をめぐる地域的共通利益の法的位置づけ, 熊本大学社 会文化研究 No.6, pp.59-84, 2008.

6) 岩橋浩文・楊穎・笹岡辰三: 地域行政における行政体の拡大と生活環境：外 部的民営化と住民参加の視角から, 熊本大学社会文化研究, No.4, pp.469-478, 2006.

7）岩橋浩文: 中高層建築物等の建築計画に対する近隣住民の条例に基づく手 続法的位置一多極的行政法の視覚から-, 熊本大学社会文化研究 No.5, pp.31-54, 2007.

8）藤井さやか : 住民主体の住環境管理における地区計画と自主ルールの活用 方策に関する研究一横浜市内の住宅地を事例として一, 日本建築学会計画 系論文集, Vol.74, No.646, pp.2627-2635, 2009.12.

9）小山暁・後藤春彦・佐藤宏亮 : 住宅地における建築協定運営委員会を核と した住環境形成の可能性一地縁組織と連携した居住者組織の育成に向けた 指針一, 日本建築学会計画系論文集, Vol.73, No.633, pp.2389-2397, 2008. 11.

10）鈴木勘也，建築協約，文治堂書店，1985.

11）東京急行電鉄(株)田園都市事業部編 : 多摩田園都市 開発 35 年の記録, 東 京急行電鉄, 1988.

12）中井検裕：まちづくり協定の法制度的考察，都市問題，Vol.90, No.60, pp.35-50, 1999. 